\section{The impact of dynamic capabilities and market orientation on firm performance: a case study of higher education consulting firms}

\author{
El impacto de las capacidades dinámicas y la orientación al mercado \\ sobre el rendimiento de las empresas: un estudio de caso de empresas \\ consultoras de educación superior
}

Andrea Chiarelli ${ }^{\mathrm{a}, *}-\mathbb{D}$

a) Research Consulting Limited. The Ingenuity Centre. University of Nottingham Innovation Park (United Kingdom)

* Primary Contact: chiarelli.andrea@gmail.com (Andrea Chiarelli)

\begin{abstract}
Dynamic capabilities (DC) and market orientation (MO) have been described as affecting firm performance, particularly in the case of fast-changing markets. They have been analysed for a wide range of firm sizes, but research on DC in the context of sole traders and micro enterprises is scarce. To begin filling this gap, this research focuses on the effects of DC and MO on firm performance in the case of sole traders, micro and small enterprises (MSEs), using higher education (HE) consulting as a case study. HE consulting was chosen as it is comprised of numerous sole traders and MSEs and it is subjected to significant and continual change. Using a survey completed by 60 MSEs based in the UK, Europe and North America, this research found that the sensing capability is a significant determinant of firm performance, alongside what this study defines as operational MO. Furthermore, operational MO was found to significantly moderate the relationship between the learning capability and firm performance. This work suggests that (i) research on DC should be extended to sole traders and MSEs; and (ii) the business literature is ripe for a growing body of applied work on DC going beyond their theoretical validation and looking to develop practical recommendations for firms in different industry sectors.
\end{abstract}

Keywords: dynamic capabilities (DC); firm performance; market orientation (MO); consulting; higher education (HE) JEL Classification: D22; I23; L20; M10; M31

\begin{abstract}
Resumen
Muchos trabajos han descrito como las capacidades dinámicas (CD) y la orientación del mercado (OM) afectan al rendimiento de las empresas, en particular en el caso de mercados dinámicos. También, se han analizado en relación con una amplia gama de tamaños de empresas, pero las investigaciones sobre las CD en el contexto de los pequeños comercios y microempresas son escasas. Para empezar a llenar este vacío, esta investigación se centra en los efectos de las CD y la OM sobre el rendimiento de las empresas para el caso de comerciantes individuales y micro y pequeñas empresas (PYMEs), utilizando la consultoría de educación superior como estudio de caso. Se eligió la consultoría de educación superior porque está compuesta por numerosos comerciantes individuales y PYMEs y está sujeta a cambios significativos y continuos. Utilizando una encuesta completada por 60 PYMEs con base en el Reino Unido, Europa y América del Norte, esta investigación encontró que la búsqueda de oportunidades (sensing) es un determinante significativo del rendimiento de la empresa, junto con lo que este estudio define como OM operacional. Además, se encontró que el OM operacional modera significativamente la relación entre la capacidad de aprendizaje y el rendimiento de la empresa. Este trabajo sugiere que: i) la investigación sobre las CD debería ampliarse a los comerciantes individuales y a las PYMEs; y ii) la bibliografía empresarial está madura para un creciente volumen de trabajo aplicado sobre las CD que vaya más allá de su validación teórica y busque desarrollar recomendaciones prácticas para las empresas de diferentes sectores industriales.
\end{abstract}

Palabras clave: capacidades dinámicas (CD); rendimiento empresarial; orientación de mercado (OM); consultoría; educación superior (ES)

Clasificación JEL: D22; I23; L20; M10; M31 


\section{Introduction}

The resource-based view (RBV) depicts firms as collections of resources that can be leveraged to achieve competitive advantage (Barney, 1991; Penrose, 2009). Among these, capabilities play an important role as "organizationally embedded non-transferable firm-specific resource whose purpose is to improve the productivity of the other resources possessed by the firm" (Makadok, 2001, p. 389) . Not all capabilities are made equal when it comes to competitive advantage: operational (or ordinary) capabilities have been described as allowing a firm to continue operating in the present (Helfat \& Winter, 2011), while dynamic capabilities (DC, including sensing, learning, integrating and coordinating capabilities) have been called "the ultimate source of competitive advantage" (Teece et al., 1997; Cepeda \& Vera, 2007, p. 426).

Furthermore, market orientation (MO) can be conceptualised as a "philosophy or way of thinking that places the highest priority on the creation of superior customer value in the marketplace" (Tajeddini \& Ratten, 2020, p. 197). Importantly, MO has been described as having a moderating effect on the DC-performance link (Baker \& Sinkula, 2015; Kiessling et al., 2016; Morgan \& Vorhies, 2018; He et al., 2018; Hernández-Linares et al., 2020).

This research focuses on the role of DC and MO in the case of sole traders, micro and small enterprises (MSEs). The choice of small organisations as an area of focus arises from the fact that "the literature has [...] paid surprisingly little attention to SMEs despite their widespread presence and importance in the global economy" (Cucculelli et al., 2014, p. 1493); this is corroborated by several other studies, including when it comes to the relationship between DC and performance and the impact of MO (Cunningham \& Maloney, 2001; Berrone et al., 2014; Ajayi et al., 2017; Beltran \& Ramesh, 2018). In addition, García-Morales et al. (2007) stated that "because large-firm management is fundamentally different from that of SMEs, conclusions drawn from many studies cannot be applied to SMEs without empirical confirmation" (p. 548): although the number of studies focusing on small firms has increased over the past ten years, the body of evidence covering these remains small compared to the case of larger organisations.

Small firms "have several characteristics not found in large-sized counterparts" (Hermawati, 2020, p. 199) and are known for having less formal organisational structures compared to larger firms. Although the employees of small firms often possess multiple skills that enhance the flexibility of the organisation (Ajayi et al., 2017; Hermawati, 2020), issues of resource orchestration are common. For example, sole traders and MSEs have limited options when it comes to resources and capabilities (Drnevich \& Kriauciunas, 2011; Sawers et al., 2008; Hernández-Linares et al., 2020), which makes them more vulnerable to competition and landscape changes (Wade \& Hulland, 2004; Wang \& Shi, 2011).

This research uses higher education (HE) consulting - an industry sector characterised by the presence of numerous sole traders and MSEs - as a case study for two key reasons. First, the HE landscape is turbulent and fast-paced (Allen et al., 2002; Amaral \& Magalhães, 2002; Bugandwa Mungu Akonkwa, 2009; Felgueira \& Rodrigues, 2015): this indicates that both its direct stakeholders (e.g. universities, research funders, publishers, students) and firms working to support them can benefit from strong DC and MO. Second, HE consulting is characterised by a high level of relational proximity and closeness between consultants and customers, which directly arises from the nature of the profession (Schulte, 1965; Schulte, 1966; Richter \& Niewiem, 2006). This concept is key to DC and MO, as it can underpin organisational learning and knowledge transfer, potentially leading to better relational outcomes and understanding of client needs (Amin \& Cohendet, 2004; Bathelt \& Glückler, 2011; Doloreux \& Freel, 2016; Ashcroft et al., 2017). In addition, Raju et al. (2011) note that, as a result of relational proximity and personal closeness with customers, SMEs tend to be highly market-oriented.

This research makes a number of contributions to the strategic management literature by empirically exploring DC and MO and how these affect firm performance in the case of sole traders and MSEs in HE consulting: the sensing capability was found to be a significant determinant of firm performance, alongside what this study defines as operational MO. Particularly, this work argues that MO may be split into two components: strategic and operational MO. The former represents an intention to serve customers and consider their satisfaction as a key component of organisational strategy. On the other hand, the latter consists in practically implementing routines and approaches that enable the measurement of customer satisfaction and a firm's commitment to this. Although this distinction may not be relevant in the case of larger firms, it is key in the case of MSEs, where resources are limited and their relative prioritisation may lead to less significant efforts with regard to operational MO (even where there is a stated strategic commitment to $\mathrm{MO})$. 


\section{Theory and hypothesis development}

\subsection{Dynamic Capabilities}

The idea of firms having a bundle of specific resources that are valuable, rare, inimitable, and nonsubstitutable (VRIN) was advanced by Barney (1991) in the context of the RBV of firms. In his view, a firm with VRIN resources should be able to enjoy sustained competitive advantage.

More recent studies highlight that better resources alone are not sufficient to fully explain why certain firms perform better than others, particularly in the long term and in increasingly demanding market conditions (Eisenhardt \& Martin, 2000; Bowman \& Ambrosini, 2003; C. L. Wang \& Ahmed, 2007; Ambrosini \& Bowman, 2009; Barreto, 2010; Lin \& Wu, 2014; Jeng \& Pak, 2016; Teece, 2019; Monteiro et al., 2019; Kapoor \& Aggarwal, 2020). The literature argues that DC are needed to make better use of VRIN resources to achieve long-term sustainability and improve organisational performance, noting that the choice of business model affects a firm's DC and the viability of particular strategies available (Teece, 2018). Work in this area, however, has largely been theoretical, and there is an extent of ambiguity around the practical impact of DC on firm performance and whether any other parameters may moderate this relationship.

Building on the work on SMEs by Hernández-Linares et al. (2020) and Pavlou and El Sawy (2006; 2011), this research investigates DC as generic knowledge-related processes rather than idiosyncratic processes specific to individual firms, as this approach can yield more generalisable findings (Jantunen et al., 2012; Eriksson, 2014). Furthermore, DC are considered as a multidimensional construct whereby distinct (yet related) dimensions contribute to improving performance (Barreto, 2010).

\subsection{Sensing Capability}

As noted above, the HE landscape is subject to continual change: in a competitive and dynamic market, the sensing capability helps consulting firms discover and create opportunities and respond to threats (Pitelis \& Wagner, 2019). However, the sensing capability is also key to avoid falling behind: firms that cannot sense the market at least as well as their competitors will fail to develop the right services, in the right areas and at the right time (Yang et al., 2020). The sensing capability requires an extent of exploration, both locally, around the firm, and in the broader landscape (Foley \& Fahy, 2009; Hodgkinson \& Healey, 2011; Teece, 2014).

In the case of HE consulting, the level of relational proximity tends to be high, and relationships with networks of spatially-distributed customers are tight: consultants should be accustomed to their customers' thinking and evolving concerns, even considering that these vary frequently due to turbulent market conditions (Slater \& Narver, 1998; Chong \& Chen, 2010). Based on the above, this research hypothesises that the sensing capability enables HE consulting firms to seize changing opportunities in the external landscape, which offers them a way to enhance their performance:

H1a: The sensing capability of sole traders and MSEs in HE consulting is positively associated with their performance.

\subsection{Learning Capability}

Prester et al. (2019) describe the learning capability as "a principal mean of attaining strategic renewal" (p. 266): renewal consists in exploring new avenues and learning new ways but also in exploiting what has already been learned. A strong learning capability also allows firms to quickly resolve specific issues by the means of experimentation and repetition.

In more concrete terms, the above can be described as the ability to acquire, assimilate and use knowledge in such a way that allows the reconfiguration of the firm's resource base (Teece et al., 1997; Ambrosini \& Bowman, 2009; Lin \& Wu, 2014). For example, learning can allow existing tasks to be performed more effectively. Learning also allows firms to design and build new services based on newly acquired knowledge (Prester et al., 2019) in a flexible and responsive way that meets the needs of the changing external landscape. Importantly, the learning capability is difficult to imitate (Hernández-Linares et al., 2020), which suggests that it is has the potential to be a key source of competitive advantage.

This research hypothesises that HE consulting firms with a strong learning capability will be able to understand and absorb market changes and changes to their resource base to deliver their services flexibly and effectively, thus positively affecting performance:

H1b: The learning capability of sole traders and MSEs in HE consulting is positively associated with their performance. 


\subsection{Market Orientation}

Previous research has investigated the relationship between firm performance and MO (Najafi-Tavani et al., 2016; Yu et al., 2019; Abbu \& Gopalakrishna, 2019). Particularly, MO works alongside other capabilities (both ordinary and dynamic), and some studies have recognised it as one of the main factors enabling firms to effectively meet the needs of their customer base (Kohli \& Jaworski, 1990; Wood et al., 2000; Rodriguez Cano et al., 2004). Länsiluoto et al. (2019) note that MO has mostly been studied in the context of larger organisations: this research seeks to deepen the understanding of MO in the case of some of the sole traders and MSEs.

Jiang et al. (2020) note that MO "affects a firm's efficiency and responsiveness in acquiring, analysing and utilising [...] resources by processing market information and keeping pace with changing customer needs and market velocity" (pp. 1241-1242) . It is, therefore, natural to consider a relationship between performance MO and DC, as these are both potential sources of competitive advantage and long-term success.

The high level of relational proximity in HE consulting means that firms have the potential to develop a strong sensing capability, as they may effectively align with customer needs thanks to close relationships and personal contact (Coviello et al., 2000; Raju et al., 2011). Hernández-Linares et al. (2020) showed that MO can strengthen this sensing capability, reinforcing a firm's understanding of its market, trends and competitors, leading to superior performance. The following hypothesis is, therefore, tested:

H2a: $M O$ positively moderates the relationship between the sensing capability and performance of sole traders and MSEs in HE consulting.

In addition, Hernández-Linares et al. (2020) hypothesised that the combination of a firm's learning capability with $\mathrm{MO}$ can give rise to a better understanding of customer needs and competitors, which in turn is seen as giving rise to competitive advantage (Calantone et al., 2002). In practice, this suggests that MO can help firms focus on the right types of external information and thus improve learning: this may be important in HE, due to the multitude of stakeholder groups, interests and pace of change. Somewhat counterintuitively, however, Hernández-Linares et al. (2020) found that high MO negatively affects the relationship between learning and performance in the case of SMEs. As a result, the following hypothesis is proposed:

H2b: $M O$ negatively moderates the relationship between the learning capability and performance of sole traders and MSEs in HE consulting.

\subsection{DC and firm performance in the context of MSEs}

Sensing and learning capabilities may be observed across firms of all sizes, as they can be driven and showcased by both individuals and groups of varying sizes. However, the same does not apply to integrating and coordinating capabilities: the integrating capability is what enables firms to combine individual knowledge into the firm's operational capabilities, while the coordinating capability is seen as the ability to dynamically govern structures, processes, resources and tasks by "coordinating and managing the interdependencies among them" (Teece, 2012; Rashidirad \& Salimian, 2020, p. 594). Both integrating and coordinating capabilities focus on the collective dimension of firms and on the complexity introduced by interdependencies (Pavlou \& El Sawy, 2011; Rashidirad \& Salimian, 2020).

Rashidirad and Salimian (2020) and Hernández-Linares et al. (2020) stress the importance of integrating and coordinating capabilities in the case of small and medium enterprises (SMEs). However, Inan and Bititci (2015) highlight the differences between micro enterprises and SMEs, showing that management and organisational structures are generally simpler the smaller an enterprise is. Sole traders are even simpler from this point of view, as all roles in the organisation are played by a single individual who makes all relevant decisions (Price, 1989). As HE consulting is comprised of a large number of sole traders and MSEs, the pool of potential participants considered in this research meant that the investigation of integrating and coordinating capabilities would not be appropriate: these focus on the collective dimension and structural complexity of firms, which, as noted above, are incompatible with firms of the size considered. Furthermore, DC questionnaires on integrating and coordinating capabilities (see, e.g. (Pavlou \& El Sawy, 2011) and (Hernández-Linares et al., 2020)) use language and concepts that do not apply to sole traders and MSEs, which was confirmed via early testing of the questionnaire underpinning this research (Berrone et al., 2014). Therefore, integrating and coordinating capabilities are considered to be beyond the scope of this research. It should be noted that this is not to imply that these DC have no impact on enterprises in HE consulting, but simply means that methodologically sound hypotheses applicable to the pool of participants considered could not be formulated.

Similar considerations also apply to the investigation of firm performance. Previous research on SMEs measured performance by asking firms to qualitatively compare themselves to competitors (Pavlou \& El Sawy, 2011; Hernández-Linares et al., 2020): this approach is effective as it asks firms to rate their performance not 
in absolute terms but in relative terms (i.e. "better than", "worse than"). In the case of sole traders and MSEs, however, focusing on comparisons with competitors would not be appropriate, as these firms often don't have the resources and marketing expertise to carry out sophisticated market research (Resnick et al., 2016).

In addition, Berrone et al. (2014) tested a survey covering performance with a sample of target MSEs and found that "direct measures of the microenterprises' performance require objective information on a set of variables - including sales turnover, profitability, costs, market share, etc. - that are often difficult to obtain" (p. 485). This suggests that seeking quantitative measures of performance from MSEs may not be appropriate. Therefore, building on literature findings, this research assesses performance via a qualitative assessment of a firm's own results, rather than with reference to quantitative measures or the performance of competitors.

\subsection{Research model and hypotheses}

Figure 1 presents an overview of the hypotheses discussed so far, including the relationships between appropriate DC dimensions (sensing and learning) and performance ( $\mathrm{H} 1 \mathrm{a}$ and $\mathrm{H} 1 \mathrm{~b}$ ) and the moderating effect of $\mathrm{MO}(\mathrm{H} 2 \mathrm{a}$ and $\mathrm{H} 2 \mathrm{~b})$. An updated version of the model presented in Figure 1 is available in the Results section (Figure 2), focusing on the hypotheses that were confirmed by this research.

Figure 1. Model and Hypotheses

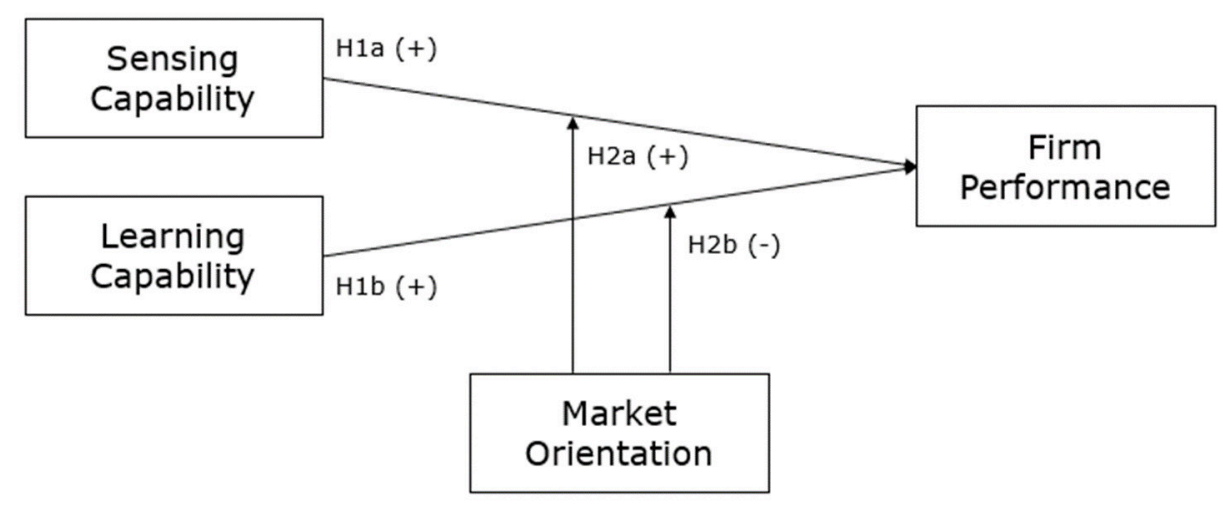

Source: Own elaboration

\section{Methods}

\subsection{Sample}

Data was gathered via a survey instrument (Appendix A), in line with recent work on DC and MO (Arend, 2013; Arend, 2014; Lin \& Wu, 2014; Beltran \& Ramesh, 2018; Hernández-Linares et al., 2020) and targeting sole traders and MSEs, up to 250 employees. The survey was open between 22 June and 13 July 2020, for a total duration of three weeks.

At present, there is no recognised dataset covering the population of HE consulting firms at the national or global level: therefore, non-random sampling was used in this study. Eligible survey participants based in the UK were identified via the Directory of Tertiary Education Consultants and the SCONUL Consultants Register (i.e. databases where HE consultants may choose to register). Furthermore, snowball sampling was used: a subset of eligible participants, when invited to complete the survey, recommended other HE consultants that should take part in this research. This process led to the identification of HE consulting MSEs based in the UK, Europe and North America, for a total of 104 potential participants. Although this approach is not likely to yield results that are representative of the entire population of $\mathrm{HE}$ consultants, it was considered as an efficient and pragmatic way to identify participants in the absence of a reliable dataset that could underpin random sampling.

Overall, 60 surveys were returned (all of which were usable), resulting in a response rate of 57.7\%. The high response rate is likely to have arisen from personalised communications and reminders sent to the prospective respondents and to the clear focus of the survey on their specific industry sector. In line with previous research on DC and MO, survey responses were analysed via correlation analysis and multiple regression analysis (using SPSS).

\subsection{Measures}

This research described DC, firm performance, MO and environmental dynamisms via constructs. The questions used consisted of Likert scales (five-point scales ranging from "strongly disagree" to "strongly agree”), as previously done in the literature (Pavlou \& El Sawy, 2011; Hernández-Linares et al., 2020). Control 
variables were assessed via text boxes and multiple-choice questions tailored to the population considered (Appendix A).

The internal consistency of constructs was assessed by calculating Chronbach's alpha values $(\alpha)$. The value of Chronbach's alpha for the survey instrument was calculated as 0.86 , while values for individual constructs are detailed in the following sections. Overall, $\alpha$ values ranged between 0.60 and 0.80 across constructs considered, which is considered to be acceptable for an exploratory analysis (Janssens et al., 2008; Ursachi et al., 2015; Taber, 2018). In addition, factor analysis was used to investigate whether constructs could be represented by a single or multiple variables.

\subsection{Dependent Variable}

Firm performance $(\alpha=0.80)$ was used as the dependent variable and consisted of a five-item scale: respondents were asked to rate how their total sales, financial profitability, service quality, customer satisfaction and competitive position changed across their last two financial years (e.g. April 2018-March 2019 vs April 2019-March 2020). The timeframe to assess performance excluded the period of the COVID-19 outbreak: this was necessary to avoid data contamination, as the impact of the economic crisis arising from the outbreak is beyond the scope of this research (McKee \& Stuckler, 2020; Sohrabi et al., 2020).

\subsection{Independent Variables}

This research focuses on the impact of sensing and learning capabilities on performance, so these were used as independent variables. Sensing and learning capabilities were measured via questions used and tested by other authors in the context of SME research (Pavlou \& El Sawy, 2011; Hernández-Linares et al., 2020). Sensing and learning capabilities were treated as individual and independent dimensions of DC and were measured via a four-item $(\alpha=0.83)$ and a five-item $(\alpha=0.77)$ scale, respectively.

\subsection{Moderating Variable}

MO ( $\alpha=0.60)$ was used as the moderating variable and was measured via an adaptation of the MORTN summary scale (Batra, 1999). The MORTN summary scale was tested with a limited portion of the survey population, and this led to a new 5-item measure of MO focusing on dimensions that could be accurately assessed by sole traders and MSEs. Particularly, this research disregarded MORTN questions discussing (i) multiple business functions/units, since these are not present in small firms; and (ii) differences in customer orientation with respect to competitors, as small firms do not typically have the capacity to carry out this type of assessment.

\subsection{Control Variables}

This investigation includes four control variables: firm size, firm age, number of university functions served and environmental dynamism (Pavlou \& El Sawy, 2006; Uhlaner et al., 2013; Wilden \& Gudergan, 2015; Hernández-Linares et al., 2020).

Control for firm size was used to account for the fact that smaller firms and sole traders may be more agile and flexible, while larger firms have more potential to focus on DC development due to higher resource availability.

Firm age was measured because this variable may affect DC and their development, particularly via patterns that develop in time within firms.

The number of university functions served was measured as this might affect performance in a turbulent and fast-paced landscape: if a firm serves more university functions, then the impact of disruptions in one of these on the whole business is less likely to be significant.

Finally, the perception of environmental dynamism $(\alpha=0.62)$ was used as a control variable because the deployment of DC is particularly relevant in a context of changing markets: particularly, it is hypothesised that DC most contribute to performance in cases where the degree of environmental dynamism is high. Responses to Q4c were discarded from the dataset as factor analysis showed that these did not contribute to perceptions of environmental dynamism $\left(\mathrm{R}^{2}=0.07\right)$.

\section{Results}

Of the 60 respondents, 34 (56.7\%) identified as independent consultants and 26 (43.3\%) identified as MSEs; staff numbers ranged between 1 and 85. Participating firms were, on average, 9.5 years old ( $\mathrm{n}=59$ ) and catered to an average of 4.3 university functions each $(n=60)$. With regard to market dynamism, respondents 
agreed or strongly agreed that changes are intense $(78.3 \%, \mathrm{n}=60)$ and take place continuously $(95.0 \%, \mathrm{n}=60)$. However, $30.0 \%$ of respondents $(n=60)$ disagreed or strongly disagreed that "customers regularly ask for services regarding completely new areas or topics" and 41.7\% $(n=60)$ shared a neutral view on this topic. Summary statistics are available in Table 1.

Table 1. Summary statistics

\begin{tabular}{|c|c|c|c|c|c|}
\hline \multicolumn{2}{|r|}{ Question } & Mean & St. dev. & Min & Max \\
\hline \multirow[t]{5}{*}{ Q1. Firm performance ${ }^{+}$} & a. Total sales & 3.69 & 1.06 & 1 & 5 \\
\hline & b. Financial profitability & 3.63 & 1.04 & 1 & 5 \\
\hline & c. Service quality & 3.64 & 0.63 & 3 & 5 \\
\hline & d. Customer satisfaction & 3.60 & 0.72 & 3 & 5 \\
\hline & e. Competitive position & 3.64 & 0.84 & 2 & 5 \\
\hline \multirow[t]{4}{*}{ Q2. Sensing capability ${ }^{++}$} & $\begin{array}{l}\text { a. My organisation frequently scans the environment to identify new } \\
\text { business opportunities. }\end{array}$ & 3.75 & 1.09 & 1 & 5 \\
\hline & $\begin{array}{l}\text { b. My organisation periodically reviews the likely effect of changes } \\
\text { in our business environment on customers. }\end{array}$ & 4.12 & 0.71 & 2 & 5 \\
\hline & $\begin{array}{l}\text { c. My organisation often reviews the services we offer to ensure they } \\
\text { are in line with what the customers want. }\end{array}$ & 4.02 & 0.79 & 2 & 5 \\
\hline & $\begin{array}{l}\text { d. My organisation devotes a lot of time implementing ideas for new } \\
\text { services and improving our existing services. }\end{array}$ & 3.35 & 1.01 & 1 & 5 \\
\hline \multirow[t]{5}{*}{ Q3. Learning capability ${ }^{++}$} & $\begin{array}{l}\text { a. My organisation has effective routines to identify, value, and } \\
\text { import new information and knowledge. }\end{array}$ & 3.80 & 0.81 & 2 & 5 \\
\hline & $\begin{array}{l}\text { b. My organisation has effective routines to assimilate new } \\
\text { information and knowledge. }\end{array}$ & 3.83 & 0.71 & 2 & 5 \\
\hline & $\begin{array}{l}\text { c. My organisation is effective in transforming existing information } \\
\text { into new knowledge. }\end{array}$ & 4.12 & 0.58 & 3 & 5 \\
\hline & $\begin{array}{l}\text { d. My organisation is effective in utilising knowledge into new } \\
\text { services. }\end{array}$ & 3.88 & 0.80 & 1 & 5 \\
\hline & $\begin{array}{l}\text { e. My organisation is effective in developing new knowledge that has } \\
\text { the potential to influence service development. }\end{array}$ & 4.00 & 0.71 & 2 & 5 \\
\hline \multirow[t]{3}{*}{$\begin{array}{l}\text { Q4. Environmental } \\
\text { dynamism }^{++}\end{array}$} & $\begin{array}{l}\text { a. In the areas of the higher education market served by my } \\
\text { organisation, environmental changes are intense. }\end{array}$ & 4.17 & 0.95 & 2 & 5 \\
\hline & $\begin{array}{l}\text { b. In the areas of the higher education market served by my } \\
\text { organisation, changes are taking place continuously. }\end{array}$ & 4.43 & 0.64 & 2 & 5 \\
\hline & $\begin{array}{l}\text { c. Customers regularly ask for services regarding completely new } \\
\text { areas or topics. }\end{array}$ & 2.98 & 0.88 & 1 & 5 \\
\hline \multirow[t]{5}{*}{ Q5. Market orientation ${ }^{++}$} & $\begin{array}{l}\text { a. Customer satisfaction is one of my organisation's key business } \\
\text { objectives. }\end{array}$ & 4.80 & 0.44 & 3 & 5 \\
\hline & $\begin{array}{l}\text { b. My organisation consistently monitors our level of commitment } \\
\text { and orientation to serving customer needs. }\end{array}$ & 3.90 & 0.93 & 1 & 5 \\
\hline & $\begin{array}{l}\text { c. My organisation's strategy for competitive advantage is based on } \\
\text { an understanding of customers' needs. }\end{array}$ & 4.33 & 0.65 & 3 & 5 \\
\hline & $\begin{array}{l}\text { d. My organisation measures customer satisfaction systematically } \\
\text { and frequently. }\end{array}$ & 3.32 & 1.09 & 1 & 5 \\
\hline & e. I believe that my organisation exists primarily to serve customers. & 4.08 & 0.82 & 2 & 5 \\
\hline
\end{tabular}

Source: Own elaboration

(+) $1=$ Decreased greatly, $2=$ Decreased slightly, $3=$ Stayed the same, $4=$ Increased slightly, $5=$ Increased greatly

$(++) 1=$ Strongly disagree, $2=$ Disagree, $3=$ Neither disagree nor agree, $4=$ Agree, $5=$ Strongly agree

Table 2 and Table 3 include the results of correlation analysis for the variables considered in standardised form (Z-scores): a wide range of statistically significant correlations were detected. Firm performance was found to be correlated with firm size $(r=0.284, p<0.05)$, sensing capability $(r=0.481, p<0.01)$ and market orientation $(\mathrm{r}=0.346, \mathrm{p}<0.01)$. The number of university functions served was found to be correlated with the sensing capability $(r=0.436, p<0.01)$, $M O(r=0.450, p<0.01)$ and firm age $(r=0.428, p<0.01)$.

Table 2. Correlations - Market Orientation as a single construct

\begin{tabular}{|c|c|c|c|c|c|c|c|c|}
\hline & (1) & (2) & (3) & (4) & (5) & (6) & (7) & (8) \\
\hline (1) Firm Performance & 1 & & & & & & & \\
\hline (2) Firm size & 0.284* & 1 & & & & & & \\
\hline (3) Firm Age & 0.093 & $0.317 *$ & 1 & & & & & \\
\hline (4) Number of university functions served & 0.190 & 0.253 & $\mathbf{0 . 4 2 8} * *$ & 1 & & & & \\
\hline (5) Environmental Dynamism & 0.040 & 0.196 & 0.157 & 0.329* & 1 & & & \\
\hline (6) Sensing Capability & $\mathbf{0 . 4 8 1} * *$ & 0.291* & 0.084 & 0.436 ** & 0.159 & 1 & & \\
\hline (7) Learning Capability & 0.160 & -0.025 & 0.037 & 0.246 & 0.038 & 0.539** & 1 & \\
\hline (8) Market Orientation & $0.346 * *$ & 0.186 & 0.105 & $\mathbf{0 . 4 5 0} * *$ & 0.139 & $0.485 * *$ & 0.424** & 1 \\
\hline
\end{tabular}

Source: Own elaboration

$\left.{ }^{*}\right) \mathrm{p}<0.05(* *) \mathrm{p}<0.01$ 
Table 3. Correlations - Impact of Strategic and Operational Market Orientation

\begin{tabular}{|c|c|c|c|c|c|c|c|c|c|}
\hline & (1) & (2) & (3) & (4) & (5) & (6) & (7) & (8) & (9) \\
\hline (1) Firm Performance & 1 & & & & & & & & \\
\hline (2) Firm size & 0.284* & 1 & & & & & & & \\
\hline (3) Firm Age & 0.093 & 0.317* & 1 & & & & & & \\
\hline (4) Number of university functions served & 0.190 & 0.253 & $0.428 * *$ & 1 & & & & & \\
\hline (5) Environmental Dynamism & 0.040 & 0.196 & 0.157 & 0.329* & 1 & & & & \\
\hline (6) Sensing Capability & $0.481 * *$ & 0.291* & 0.084 & $0.436 * *$ & 0.159 & 1 & & & \\
\hline (7) Learning Capability & 0.160 & -0.025 & 0.037 & 0.246 & 0.038 & 0.539** & 1 & & \\
\hline (8) Strategic Market Orientation & 0.096 & 0.103 & -0.026 & 0.259* & 0.086 & 0.181 & 0.064 & 1 & \\
\hline (9) Operational Market Orientation & 0.373** & 0.183 & 0.148 & $0.423 * *$ & 0.122 & $0.508 * *$ & $0.492 * *$ & 0.237 & 1 \\
\hline
\end{tabular}

Source: Own elaboration

(*) $\mathrm{p}<0.05(* *) \mathrm{p}<0.01$

Hypotheses $\mathrm{H} 1 \mathrm{a}, \mathrm{H} 1 \mathrm{~b}, \mathrm{H} 2 \mathrm{a}$ and $\mathrm{H} 2 \mathrm{~b}$ were tested using multiple regression analysis (ordinary least squares, Figure 2); condition indices for the variables considered ranged from 1.00 to 3.51, which indicates that multicollinearity is not an issue (Alin, 2010). Four models were used to analyse the data, considering performance as the dependent variable in all cases (Table 4). In Model 1, only control variables were included, and firm size was significantly related to performance $(\beta=0.279, p<0.1)$.

Figure 2. Results (Model 4a)

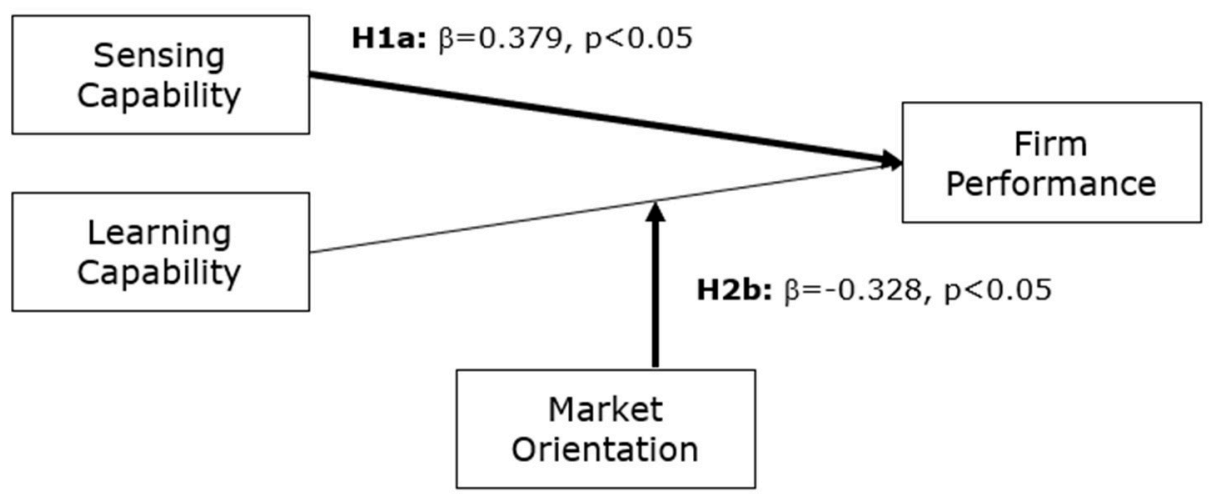

\begin{tabular}{|c|c|}
\hline Hypothesis & Outcome \\
\hline H1a (+) & Supported \\
\hline H1b (+) & Not supported \\
\hline H2a (+) & Not supported \\
\hline H2b (-) & Supported \\
\hline
\end{tabular}

Source: Own elaboration

To test $\mathrm{H} 1 \mathrm{a}$ and $\mathrm{H} 1 \mathrm{~b}$, the learning and sensing capabilities were included in Model 2, which caused an increase in $R^{2}\left(\Delta R^{2}=17.1 \%\right)$. In this case, only the sensing capability had a significant positive association with performance, which supports H1a but means that H1b is not supported.

To test the moderation effect hypothesised in $\mathrm{H} 2 \mathrm{a}$ and $\mathrm{H} 2 \mathrm{~b}$, MO was included in Model 3a, and the interaction terms were included in Model 4a: a significant change in $\mathrm{R}^{2}$ was observed in both cases (Model $3 a: \Delta \mathrm{R}^{2}=3.4 \%$, Model 4a: $\Delta \mathrm{R}^{2}=7.9 \%$ ). No significant relationship was detected between $\mathrm{MO}$ and performance (Model 3a), and only $\mathrm{H} 2 \mathrm{~b}$ was supported $(\beta=-0.328, \mathrm{p}<0.05)$.

In addition, factor analysis highlighted that two variables were needed to explain the majority of the total variance for MO (varimax method). Therefore, even if previous research in the literature described MO as a single variable, this research considered an additional level of analysis where MO was split into two components: strategic MO (Q5a and Q5e) and operational MO (Q5b-Q5d) (Table 3). Strategic MO is here defined as an organisational commitment to serve and satisfy customers, while operational MO is defined as the set of organisational processes to implement the above in practice (i.e. monitoring MO, understanding customer needs, measuring customer satisfaction).

The split between strategic and operational MO was based on the extent to which each MO-related question contributed to the two variables identified by factor analysis. This approach highlights that, although MO does not have a significant relationship with performance (Model 3a), operational MO does $(\beta=0.259, \mathrm{p}<0.1$ in Model 3b and $\beta=0.275, p<0.1$ in Model $4 b$ ). 
A comparison between Model 4a and Model 4b confirms the relationship between performance and sensing capability, but it also sheds more light on the moderation effect of MO on a firm's learning capability: it appears that the moderation effect detected is largely due to operational $\mathrm{MO}(\beta=-0.381, \mathrm{p}<0.05)$, rather than to strategic $\mathrm{MO}(\beta=0.065$, n.s.).

In terms of the difference between the models studied (Table 4), Model 1 explained 10.9\% of the variance, while the addition of DC and MO explained an additional $17.1 \%$ and $3.4 \%$, respectively. The inclusion of interactive effects covered an additional 7.9\%. Although models $3 \mathrm{~b}$ and $4 \mathrm{~b}$ clarify the relative impact of operational MO and strategic MO, they are not preferable to Models $3 a$ and 4 a due to their lower adjusted $\mathrm{R}^{2}$ values.

Table 4. Results of Multiple Regression Analysis

\begin{tabular}{|c|c|c|c|c|c|c|}
\hline & Model 1 & Model 2 & Model 3a & Model 4a & Model 3b & Model 4b \\
\hline Firm size & $0.279^{+}$ & 0.150 & 0.132 & 0.133 & 0.131 & 0.119 \\
\hline Firm Age & -0.067 & 0.002 & 0.013 & -0.077 & -0.002 & -0.075 \\
\hline Number of university functions served & 0.187 & -0.012 & -0.082 & 0.034 & -0.078 & 0.031 \\
\hline Environmental Dynamism & -0.080 & -0.079 & -0.079 & -0.084 & -0.074 & -0.114 \\
\hline Sensing Capability & & $\mathbf{0 . 5 2 9} * *$ & $\mathbf{0 . 4 9 1} * *$ & 0.379* & $\mathbf{0 . 4 8 1} * *$ & 0.373* \\
\hline Learning Capability & & -0.115 & -0.178 & -0.114 & -0.204 & -0.221 \\
\hline Market Orientation (MO) & & & 0.229 & 0.233 & & \\
\hline Strategic Market Orientation & & & & & 0.022 & 0.060 \\
\hline Operational Market Orientation & & & & & $0.259^{+}$ & $0.275^{+}$ \\
\hline MO*Sensing Capability & & & & 0.036 & & \\
\hline MO*Learning Capability & & & & $-0.328 *$ & & \\
\hline Strategic MO*Sensing Capability & & & & & & -0.018 \\
\hline Strategic MO*Learning Capability & & & & & & 0.065 \\
\hline Operational MO*Sensing Capability & & & & & & 0.065 \\
\hline Operational MO*Learning Capability & & & & & & $-0.381 *$ \\
\hline $\mathbf{R}^{2}$ & 0.109 & 0.280 & 0.314 & 0.393 & 0.323 & 0.422 \\
\hline Adjusted $\mathbf{R}^{2}$ & 0.040 & 0.193 & 0.216 & 0.277 & 0.210 & 0.264 \\
\hline $\mathbf{F}$ & 1.587 & $3.237 * *$ & $3.209 * *$ & $3.386^{* *}$ & $2.863^{* *}$ & $2.674^{* *}$ \\
\hline
\end{tabular}

Source: Own elaboration

(*) $\mathrm{p}<0.05{ }^{(* *)} \mathrm{p}<0.01(+) \mathrm{p}<0.1$

\section{Discussion}

This research investigated the impact of DC on performance and the moderating effect of MO on the DCperformance link. It followed the approach outlined by Pavlou and El Sawy (2011) and Hernández-Linares et al. (2020), including a range of adaptations to suit in-scope firms.

The data gathered shows that the sensing capability is positively and significantly associated with performance, while this is not the case for the learning capability. In the first place, this shows that, as outlined in previous work, the different dimensions of DC need to be considered separately rather than as a single construct that could hide the relative impact of distinct capabilities.

Hernández-Linares et al. (2020) showed that the sensing capability is not positively associated with performance, while the opposite is true here. The difference in findings is important for two reasons: firstly, it shows that some DC can affect performance in the case of sole traders and MSEs, which potentially opens the field of DC to the smallest forms of organisations. Secondly, it suggests that the analysis of DC is likely to be affected by industry sector(s): previous work on DC in SMEs tended to focus on a wider range of firms from different industry sectors and in aggregate form, while the present research analyses HE consulting more specifically.

The focus on HE consulting highly affects results: responding firms have shared high perceptions of environmental dynamism, which clarifies why the sensing capability is key. Hernández-Linares et al. (2020) note that SMEs have high personal contact with customers and sensing may not be a rare capability: although personal contact with customer is high in the case of HE consulting, sensing can in fact be a differentiating capability and source of improved performance, as this is one of the few ways firms can keep up with continual and intense market changes.

On the other hand, the relationship between performance and the learning capability was not statistically significant (H1b), unlike the findings of Hernández-Linares et al. (2020). The definition of the learning capability can provide insight into this: the learning capability is considered as a tool for firms to (i) reconfigure their resource base; or (ii) design and build new services to meet changing market needs. However, the former activity may have little relevance to the sample of respondents considered in this 
research, as many of these were sole traders or micro enterprises, with (very) limited scope for reconfiguring their resource bases. The latter activity may be more relevant, but empirical results showed that customers tend not to ask for services regarding new areas of topics: therefore, the learning capability has a limited impact on performance for the sample of participants considered.

Another key finding of this research is that MO could be split into strategic and operational MO. While the former was not associated with performance, the latter was: this shows that a strategic commitment to serving customers is not as impactful as the set of organisational processes that enable this in practice. Operational MO may be pursued by the means of a quality management system or other frameworks to assess customer satisfaction (e.g. ISO9001, SERVQUAL, SERVPERF) (Samat et al., 2006; Bradshaw et al., 2008; Laforet, 2009; Rodrigues et al., 2011), and, in the context of sole traders and MSEs, it has the potential to be a source of competitive advantage. With small staff numbers and resource constraints (Lu \& Beamish, 2001; Døving \& Gooderham, 2008), the decision to devote staff time to non-income-generating activities is always carefully assessed against expected financial returns: this research suggests that overall performance can be positively affected by activities supporting operational MO.

The findings discussed so far are important to broaden the understanding of DC in the context sole traders and MSEs and to identify ways these can remain competitive in fast-paced and shifting markets. The abovementioned issue of limited resources is particularly important in the context of sole traders. Independent consultants need to manage their firm, deliver consultancy projects and develop strategic capabilities: therefore, it is essential to find the right balance between these to ensure short-to-medium term financial returns and long-term sustainability. As firms grow, the time available for strategic development (including DC) may potentially increase, although deciding how to invest this remains a key concern for decisionmakers.

In terms of the moderating effect of MO on the DC-performance link, H2a proposed an enhancing effect on the sensing-performance link, while $\mathrm{H} 2 \mathrm{~b}$ proposed a negative effect on the learning-performance link. Only $\mathrm{H} 2 \mathrm{~b}$ was confirmed, and this is in line with the findings of Hernández-Linares et al. (2020). The present research further investigated $\mathrm{H} 2 \mathrm{~b}$ by differentiating between strategic $\mathrm{MO}$ and operational MO: it found that operational MO is responsible for the negative moderating effect detected. This highlights that, in the case of HE consulting firms, a high learning capability is not going to negatively affect performance by itself, but this will be the case if operational MO is also high.

In sum, this research contributes to the evolving body of knowledge on DC, using empirical data from sole traders and MSEs in HE consulting. Findings applicable to HE consulting firms are not likely to be valid more broadly, but this research does show that DC can play an important role for sole traders and MSEs - an area that has received very limited attention in the literature even if, for example, businesses with 0-49 employees accounted for 99.3\% of the UK business population in 2019 (Department for Business Energy \& Industrial Strategy, 2020).

Finally, this research furthers the understanding of MO by splitting it into strategic and operational MO. Although this may not be necessary for larger firms, the difference between the two becomes apparent in much smaller contexts, as staff time needs to be spent on activities that are most closely linked with enhanced performance (particularly when these activities are internal and do not directly generate income).

\section{Conclusions and recommendations}

This research investigates the impact of DC on sole traders and MSEs in HE consulting. Particularly, it finds that the sensing capability is positively associated with performance, and so is what has been defined as operational MO. This suggests that consultants serving the HE landscape should focus on these to achieve superior performance. On the other hand, the learning capability was not found to affect performance in the sample considered, but empirical data showed that operational MO moderates the learning capabilityperformance link.

With regard to the sensing capability, it is interesting to point out that HE consultants already have a close relationship with their customers. It is therefore recommended that $\mathrm{HE}$ consultants cultivate these relationships (e.g. increasing the frequency, depth and breadth of connections) and seek to develop better and more structured routines to scan the landscape and avoid falling behind. Although this research found that customers don't tend to regularly ask for services regarding new areas or topics, the environment has been defined as highly dynamic. This suggests that the sensing capability will be key internally, to develop organisational strategies and define a firm's focus on specific university functions, but also externally, e.g. to build a firm's credibility to prospective customers and to contextualise the findings of consultancy assignments in a complex and evolving multi-stakeholder context.

In the case of $\mathrm{MO}$, the empirical data suggests that a strategic commitment to serving customers is not a determinant of good performance, while operational MO is. Therefore, it is recommended that HE consultants ensure that the right organisational structures and routines are in place to (i) monitor customer satisfaction 
and MO and (ii) enhance their understanding of customer needs. The former objective can be approached by developing quality management systems and/or by strengthening a firm's ability to secure and monitor customer feedback. The latter can be approached by the means of market research and by strengthening relationships with key stakeholders.

It is important to specify that the above findings and recommendations are valid at this point in time and for HE consultants only: although some of the concepts discussed in this work are of more general interest, it should be noted that this research was developed as a case study of DC and MO in HE consulting, with a focus on sole traders and MSEs. For instance, these findings are likely not to be applicable in any cases where perceptions of market dynamism are low or firms are much larger.

\subsection{Directions for Future Research}

This research also gave rise to theoretical insights of broader validity. First, it shows that some DC apply to the smallest forms of organisations, down to the level of sole traders. Second, the findings suggest that the investigation of DC may need to be carried out separately for different industry sectors if actionable insights are to be developed.

Previous research on the topic tended to focus on the theory of DC and MO and their impact on different firm sizes (e.g. corporate/industry or SMEs), which means that the development of specific insights has rarely been pursued. Hernández-Linares et al. (2020) highlight the limitations of cross-sectional designs and note that these restrict a researcher's ability to infer causality from findings: clearly, correlations derived for a large dataset of firms in different industry sectors are needed to validate business theories, but they are not suitable to develop practical recommendations. To date, DC and MO have been confirmed by several authors to affect performance: the business literature may therefore be ripe for more sector-specific studies (such as the present one), seeking to support firms from a more practical perspective and considering the differences between strategic and operational MO across firms of different sizes.

Further research should also seek to discuss environmental dynamism beyond the boundaries of a specific industry sector (e.g. HE): any insights arising from similar work and survey instruments will need to consider the broader economic context to be applicable in practice. For example, to what extent are perceptions of environmental dynamism related with broader economic phenomena (e.g. the post-COVID economy), and how could this relationship affect performance? This points to the temporary nature of these findings, and confirms the suggestion by Hernández-Linares et al. (2020) that longitudinal approaches may be beneficial in the analysis of DC and MO.

\subsection{Limitations}

The main limitation of this research is the non-random sampling method used: the 60 responding MSEs, although representing a majority of the eligible participants invited, may not be representative of HE consulting more broadly. Furthermore, it should be noted that multiple regression analysis is not ideal to discuss effects or impact, but can only assess association or correlation.

The methodology underpinning the present research was based on previous work in the literature. Future work may build on the findings of this research to try and identify whether any confounding factors play a role in determining any of the relationships detected here: for example, variables omitted in the present research (including work ethic and quality of management) might affect DC, MO and performance. Finally, the methodology followed is not suitable to assess whether MO is causing improved performance or more successful firms invest more in MO-related activities, which suggests that further research may be needed to investigate causal relationships.

\section{Acknowledgments}

I would like to thank Alessio Gaggero (Universidad de Granada) for his insightful feedback and comments over the course of this research project. 


\section{Appendix A}

This appendix includes the questions used in the context of this research, which are based on previous work on DC and MO (Pavlou \& El Sawy, 2011; Hernández-Linares et al., 2020). The full survey instrument also included generic questions on topics such as firm size and age, which are not included here in the interest of brevity. It should be noted that the survey was anonymous and did not collect any form of personal information within the scope of the UK Data Protection Act 2018 or the General Data Protection Regulation.

Table 5. Survey instrument

Firm performance

Q1. Please compare your organisation's performance across your last two financial years (e.g. April 2018-March 2019 vs April 2019-March 2020). How have the following performance indicators changed within this period?

[Five-point Likert scale, from "Decreased greatly"to "Increased greatly"]
a. Total sales
b. Financial profitability
c. Service quality
d. Customer satisfaction
e. Competitive position

\section{Sensing capability}

Q2. To what extent do you agree with the following?

[Five-point Likert scale, from "Strongly disagree" to "Strongly agree"]

a. My organisation frequently scans the environment to identify new business opportunities

b. My organisation periodically reviews the likely effect of changes in our business environment on customers

c. My organisation often reviews the services we offer to ensure they are in line with what the customers want

d. My organisation devotes a lot of time implementing ideas for new services and improving our existing services

\section{Learning capability}

Q3. To what extent do you agree with the following?

[Five-point Likert scale, from "Strongly disagree" to "Strongly agree"]

a. My organisation has effective routines to identify, value, and import new information and knowledge

b. My organisation has effective routines to assimilate new information and knowledge

c. My organisation is effective in transforming existing information into new knowledge

d. My organisation is effective in utilising knowledge into new services

e. My organisation is effective in developing new knowledge that has the potential to influence service development

\section{Environmental dynamism}

Q4. Please consider the areas of the higher education market served by your organisation: to what extent do you agree with the following?

[Five-point Likert scale, from "Strongly disagree" to "Strongly agree"]

a. In the areas of the higher education market served by my organisation, environmental changes are intense

b. In the areas of the higher education market served by my organisation, changes are taking place continuously

c. Customers regularly ask for services regarding completely new areas or topics

\section{Market orientation}

Q5. To what extent do you agree with the following?

[Five-point Likert scale, from "Strongly disagree" to "Strongly agree"]

a. Customer satisfaction is one of my organisation's key business objectives

b. My organisation consistently monitors our level of commitment and orientation to serving customer needs

c. My organisation's strategy for competitive advantage is based on an understanding of customers' needs

d. My organisation measures customer satisfaction systematically and frequently

e. I believe that my organisation exists primarily to serve customers 


\section{References}

Abbu, H. R., \& Gopalakrishna, P. (2019). Synergistic effects of market orientation implementation and internalization on firm performance: Direct marketing service provider industry. Journal of Business Research. https://doi.org/10.1016/j.jbusres.2019.06.004

Ajayi, O. M., Odusanya, K., \& Morton, S. (2017). Stimulating employee ambidexterity and employee engagement in SMEs. Management Decision, 55(4), 662-680. https://doi.org/10.1108/MD-02-2016-0107

Alin, A. (2010). Multicollinearity. Wiley Interdisciplinary Reviews: Computational Statistics, 2(3), 370-374. https://doi.org/10.1002/wics.84

Allen, D., Kern, T., \& Mattison, D. (2002). Culture, power and politics in ICT outsourcing in higher education institutions. European Journal of Information Systems, 11(2), 159-173. https://doi.org/10.1057/palgrave/ejis/3000425

Amaral, A., \& Magalhães, A. (2002). The Emergent Role of External Stakeholders in European Higher Education Governance. In A. Amaral, G. A. Jones, \& B. Karseth (Eds.), Governing Higher Education: National Perspectives on Institutional Governance (pp. 1-21). Springer Netherlands. https://doi.org/10.1007/978-94-015-9946-7 1

Ambrosini, V., \& Bowman, C. (2009). What are dynamic capabilities and are they a useful construct in strategic management? International Journal of Management Reviews, 11(1), 29-49. https://doi.org/10.1111/j.1468-2370.2008.00251.x

Amin, A., \& Cohendet, P. (2004). Architectures of knowledge: firms, capabilities, and communities. Oxford University Press. https://doi.org/10.1093/acprof:oso/9780199253326.001.0001

Arend, R. J. (2013). Ethics-focused dynamic capabilities: a small business perspective. Small Business Economics, 41(1), 1-24. https://doi.org/10.1007/s11187-012-9415-2

Arend, R. J. (2014). Entrepreneurship and dynamic capabilities: how firm age and size affect the 'capability enhancement-SME performance' relationship. Small Business Economics, 42(1), 33-57. https://doi.org/10.1007/s11187-012-9461-9

Ashcroft, J., Childs, R., Myers, A., \& Schluter, M. (2017). The Relational Lens: Understanding, Managing and Measuring Stakeholder Relationships. Cambridge University Press. https://doi.org/10.1017/CBO9781316659212

Baker, W. E., \& Sinkula, J. M. (2015). Market Orientation and Organizational Performance: A New Product Paradox? In H. E. Spotts (Ed.), Creating and Delivering Value in Marketing (pp. 254-254). Springer International Publishing. https://doi.org/10.1007/978-3-319-11848-2_96

Barney, J. (1991). Firm Resources and Sustained Competitive Advantage. Journal of Management, 17(1), 99-120. https://doi.org/10.1177/014920639101700108

Barreto, I. (2010). Dynamic Capabilities: A Review of Past Research and an Agenda for the Future. Journal of Management, 36(1), 256-280. https://doi.org/10.1177/0149206309350776

Bathelt, H., \& Glückler, J. (2011). The Relational Economy: Geographies of Knowing and Learning. Oxford University Press. https://doi.org/10.1093/acprof:osobl/9780199587384.001.0001

Batra, R. (Ed.). (1999). Marketing Issues in Transitional Economies. Springer US. https://doi.org/10.1007/978-1-4615-5009-9

Beltran, G., \& Ramesh, B. (2018). Dynamic Capabilities in Small Service Firms. Engaged Management ReView, 1(3). https://doi.org/10.28953/2375-8643.1018

Berrone, P., Gertel, H., Giuliodori, R., Bernard, L., \& Meiners, E. (2014). Determinants of Performance in Microenterprises: Preliminary Evidence from Argentina. Journal of Small Business Management, 52(3), 477-500. https://doi.org/10.1111/jsbm.12045

Bowman, C., \& Ambrosini, V. (2003). How the Resource-based and the Dynamic Capability Views of the Firm Inform Corporate-level Strategy. British Journal of Management, 14(4), 289-303. https://doi.org/10.1111/j.1467-8551.2003.00380.x

Bradshaw, R., Maycock, C., \& Öztel, H. (2008). Exploring SME market orientation: an organisational learning perspective. Education + Training, 50(8/9), 764-777. https://doi.org/10.1108/00400910810917127

Bugandwa Mungu Akonkwa, D. (2009). Is market orientation a relevant strategy for higher education institutions? Context analysis and research agenda. International Journal of Quality and Service Sciences, 1(3), 311-333. https://doi.org/10.1108/17566690911004230

Calantone, R. J., Cavusgil, S. T., \& Zhao, Y. (2002). Learning orientation, firm innovation capability, and firm performance. Industrial Marketing Management, 31(6), 515-524. https://doi.org/10.1016/S0019-8501(01)00203-6

Cepeda, G., \& Vera, D. (2007). Dynamic capabilities and operational capabilities: A knowledge management perspective. Journal of Business Research, 60(5), 426-437. https://doi.org/10.1016/j.jbusres.2007.01.013

Chong, Y. T., \& Chen, C. (2010). Management and forecast of dynamic customer needs: An artificial immune and neural system approach. Advanced Engineering Informatics, 24(1), 96-106.

https://doi.org/10.1016/j.aei.2009.06.003 
Coviello, N. E., Brodie, R. J., \& Munro, H. J. (2000). An investigation of marketing practice by firm size. Journal of Business Venturing, 15(5-6), 523-545. https://doi.org/10.1016/S0883-9026(98)00035-4

Cucculelli, M., Bettinelli, C., \& Renoldi, A. (2014). How small-medium enterprises leverage intangibles during recessions. Evidence from the Italian clothing industry. Management Decision, 52(8), 1491-1515. https://doi.org/10.1108/MD-01-2014-0034

Cunningham, W. V., \& Maloney, W. F. (2001). Heterogeneity among Mexico's Microenterprises: An Application of Factor and Cluster Analysis. Economic Development and Cultural Change, 50(1), 131-156. https://doi.org/10.1086/340012

Department for Business Energy \& Industrial Strategy (2020, July 17). Business Population Estimates 2019. https://www.gov.uk/government/statistics/business-population-estimates-2019

Doloreux, D., \& Freel, M. (2016). Knowledge-intensive business services: geography and innovation. Routledge

Drnevich, P. L., \& Kriauciunas, A. P. (2011). Clarifying the conditions and limits of the contributions of ordinary and dynamic capabilities to relative firm performance. Strategic Management Journal, 32(3), 254-279. https://doi.org/10.1002/smj.882

Døving, E., \& Gooderham, P. N. (2008). Dynamic capabilities as antecedents of the scope of related diversification: the case of small firm accountancy practices. Strategic Management Journal, 29(8), 841-857. https://doi.org/10.1002/smj.683

Eisenhardt, K. M., \& Martin, J. A. (2000). Dynamic capabilities: what are they? Strategic Management Journal, 21(10-11), 1105-1121. https://doi.org/10.1002/1097-0266(200010/11)21:10/11<1105::AIDSMJ133>3.0.CO;2-E

Eriksson, T. (2014). Processes, antecedents and outcomes of dynamic capabilities. Scandinavian Journal of Management, 30(1), 65-82. https://doi.org/10.1016/j.scaman.2013.05.001

Felgueira, T., \& Rodrigues, R. G. (2015). Market Orientation of Teachers and Researchers in Higher Education Institutions: A New Approach. Procedia - Social and Behavioral Sciences, 174, 3017-3024. https://doi.org/10.1016/j.sbspro.2015.01.1092

Foley, A., \& Fahy, J. (2009). Seeing market orientation through a capabilities lens. European Journal of Marketing, 43(1/2), 13-20. https://doi.org/10.1108/03090560910923201

García-Morales, V. J., Lloréns-Montes, F. J., \& Verdú-Jover, A. J. (2007). Influence of personal mastery on organizational performance through organizational learning and innovation in large firms and SMEs. Technovation, 27(9), 547-568. https://doi.org/10.1016/j.technovation.2007.02.013

He, X., Brouthers, K. D., \& Filatotchev, I. (2018). Market orientation and export performance: the moderation of channel and institutional distance. International Marketing Review, 35(2), 258-279. https://doi.org/10.1108/IMR-09-2015-0194

Helfat, C. E., \& Winter, S. G. (2011). Untangling Dynamic and Operational Capabilities: Strategy for the (N)ever-Changing World. Strategic Management Journal, 32(11), 1243-1250. https://doi.org/10.1002/smj.955

Hermawati, A. (2020). The implementation of dynamic capabilities for SMEs in creating innovation. Journal of Workplace Learning, 32(3), 199-216. https://doi.org/10.1108/JWL-06-2019-0077

Hernández-Linares, R., Kellermanns, F. W., \& López-Fernández, M. C. (2020). Dynamic capabilities and SME performance: The moderating effect of market orientation. Journal of Small Business Management, 1-34. https://doi.org/10.1111/jsbm.12474

Hodgkinson, G. P., \& Healey, M. P. (2011). Psychological foundations of dynamic capabilities: reflexion and reflection in strategic management. Strategic Management Journal, 32(13), 1500-1516. https://doi.org/10.1002/smj.964

Inan, G. G., \& Bititci, U. S. (2015). Understanding Organizational Capabilities and Dynamic Capabilities in the Context of Micro Enterprises: A Research Agenda. Procedia - Social and Behavioral Sciences, 210, 310-319. https://doi.org/10.1016/j.sbspro.2015.11.371

Janssens, W., Wijnen, K., Pelsmacker, P. D., \& Kenhove, P. V. (2008). Marketing Research with SPSS. Prentice Hall

Jantunen, A., Ellonen, H., \& Johansson, A. (2012). Beyond appearances - Do dynamic capabilities of innovative firms actually differ? European Management Journal, 30(2), 141-155. https://doi.org/10.1016/j.emj.2011.10.005

Jeng, D. J., \& Pak, A. (2016). The variable effects of dynamic capability by firm size: the interaction of innovation and marketing capabilities in competitive industries. International Entrepreneurship and Management Journal, 12(1), 115-130. https://doi.org/10.1007/s11365-014-0330-7

Jiang, W., Mavondo, F., \& Zhao, W. (2020). The impact of business networks on dynamic capabilities and product innovation: The moderating role of strategic orientation. Asia Pacific Journal of Management, 37(4), 1239-1266. https://doi.org/10.1007/s10490-018-9628-2

Kapoor, M., \& Aggarwal, V. (2020). Tracing the economics behind dynamic capabilities theory. International Journal of Innovation Science, 12(2), 187-201. https://doi.org/10.1108/IJIS-05-2019-0050 
Kiessling, T., Isaksson, L., \& Yasar, B. (2016). Market Orientation and CSR: Performance Implications. Journal of Business Ethics, 137(2), 269-284. https://doi.org/10.1007/s10551-015-2555-y

Kohli, A. K., \& Jaworski, B. J. (1990). Market Orientation: The Construct, Research Propositions, and Managerial Implications. Journal of Marketing, 54(2), 1-18.

https://doi.org/10.1177/002224299005400201

Laforet, S. (2009). Effects of size, market and strategic orientation on innovation in non-high-tech manufacturing SMEs. European Journal of Marketing, 43(1/2), 188-212. https://doi.org/10.1108/03090560910923292

Lin, Y., \& Wu, L. (2014). Exploring the role of dynamic capabilities in firm performance under the resourcebased view framework. Journal of Business Research, 67(3), 407-413. https://doi.org/10.1016/j.jbusres.2012.12.019

Lu, J. W., \& Beamish, P. W. (2001). The internationalization and performance of SMEs. Strategic Management Journal, 22(6-7), 565-586. https://doi.org/10.1002/smj.184

Länsiluoto, A., Joensuu-Salo, S., Varamäki, E., Viljamaa, A., \& Sorama, K. (2019). Market Orientation and Performance Measurement System Adoption Impact on Performance in SMEs. Journal of Small Business Management, 57(3), 1027-1043. https://doi.org/10.1111/jsbm.12393

Makadok, R. (2001). Toward a synthesis of the resource-based and dynamic-capability views of rent creation. Strategic Management Journal, 22(5), 387-401. https://doi.org/10.1002/smj.158

McKee, M., \& Stuckler, D. (2020). If the world fails to protect the economy, COVID-19 will damage health not just now but also in the future. Nature Medicine, 26(5), 640-642. https://doi.org/10.1038/s41591-020-0863-y

Monteiro, A. P., Soares, A. M., \& Rua, O. L. (2019). Linking intangible resources and entrepreneurial orientation to export performance: The mediating effect of dynamic capabilities. Journal of Innovation $\&$ Knowledge, 4(3), 179-187. https://doi.org/10.1016/j.jik.2019.04.001

Morgan, N. A., \& Vorhies, D. W. (2018). The Business Performance Outcomes of Market Orientation Culture and Behaviors. In R. Varadarajan, \& S. Jayachandran (Eds.), Review of Marketing Research (pp. 255-282). https://doi.org/10.1108/S1548-643520180000015012

Najafi-Tavani, S., Sharifi, H., \& Najafi-Tavani, Z. (2016). Market orientation, marketing capability, and new product performance: The moderating role of absorptive capacity. Journal of Business Research, 69(11), 5059-5064. https://doi.org/10.1016/j.jbusres.2016.04.080

Pavlou, P. A., \& El Sawy, O. A. (2006). From IT Leveraging Competence to Competitive Advantage in Turbulent Environments: The Case of New Product Development. Information Systems Research, 17(3), 198-227. https://doi.org/10.1287/isre.1060.0094

Pavlou, P. A., \& El Sawy, O. A. (2011). Understanding the Elusive Black Box of Dynamic Capabilities. Decision Sciences, 42(1), 239-273. https://doi.org/10.1111/j.1540-5915.2010.00287.x

Penrose, E. (2009). The Theory of the Growth of the Firm. Oxford University Press. https://doi.org/10.1093/0198289774.001.0001

Pitelis, C. N., \& Wagner, J. D. (2019). Strategic Shared Leadership and Organizational Dynamic Capabilities. The Leadership Quarterly, 30(2), 233-242. https://doi.org/10.1016/j.leaqua.2018.08.002

Prester, J., Hernaus, T., Aleksić, A., \& Trkman, P. (2019). Performance Effects of Dynamic Capabilities: The Interaction Effect of Process Management Capabilities. In C. Di Ciccio, R. Gabryelczyk, L. GarcíaBañuelos, T. Hernaus, R. Hull, M. Indihar Štemberger, A. Kő, \& M. Staples (Eds.), Business Process Management: Blockchain and Central and Eastern Europe Forum (pp. 264-279). Springer International Publishing. https://doi.org/10.1007/978-3-030-30429-4_18

Price, T. (1989). Business organisation. In Mastering Background to Business (pp. 19-39). Macmillan Education UK. https://doi.org/10.1007/978-1-349-19833-7_2

Raju, P. S., Lonial, S. C., \& Crum, M. D. (2011). Market orientation in the context of SMEs: A conceptual framework. Journal of Business Research, 64(12), 1320-1326.

https://doi.org/10.1016/j.jbusres.2010.12.002

Rashidirad, M., \& Salimian, H. (2020). SMEs' dynamic capabilities and value creation: the mediating role of competitive strategy. European Business Review, 32(4), 591-613. https://doi.org/10.1108/EBR-06-2019-0113

Resnick, S. M., Cheng, R., Simpson, M., \& Lourenço, F. (2016). Marketing in SMEs: a “4Ps” self-branding model. International Journal of Entrepreneurial Behavior \& Research, 22(1), 155-174. https://doi.org/10.1108/IJEBR-07-2014-0139

Richter, A., \& Niewiem, S. (2006). The relationship between clients and management consultants: An empirical analysis. Academy of Management Proceedings, 2006(1). https://doi.org/10.5465/ambpp.2006.27168710

Rodrigues, L. L. R., Barkur, G., Varambally, K. V. M., \& Golrooy Motlagh, F. (2011). Comparison of SERVQUAL and SERVPERF metrics: an empirical study. The TQM Journal, 23(6), 629-643. https://doi.org/10.1108/17542731111175248 
Rodriguez Cano, C., Carrillat, F. A., \& Jaramillo, F. (2004). A meta-analysis of the relationship between market orientation and business performance: evidence from five continents. International Journal of Research in Marketing, 21(2), 179-200. https://doi.org/10.1016/j.ijresmar.2003.07.001

Samat, N., Ramayah, T., \& Mat Saad, N. (2006). TQM practices, service quality, and market orientation. Management Research News, 29(11), 713-728. https://doi.org/10.1108/01409170610716025

Sawers, J. L., Pretorius, M. W., \& Oerlemans, L. A. G. (2008). Safeguarding SMEs dynamic capabilities in technology innovative SME-large company partnerships in South Africa. Technovation, 28(4), $171-182$. https://doi.org/10.1016/j.technovation.2007.09.002

Schulte, A. (1965). Compatibility of Management Consulting and Auditing. The Accounting Review, 40(3), 587-593. www.jstor.org/stable/243065

Schulte, A. (1966). Management Services: A Challenge to Audit Independence? The Accounting Review, 41(4), 721-728. https://www.jstor.org/stable/243588

Slater, S. F., \& Narver, J. C. (1998). Customer-led and market-oriented: let's not confuse the two. Strategic Management Journal, 19(10), 1001-1006. https://doi.org/10.1002/(SICI)1097-0266(199810)19:10<1001::AID-SMJ996>3.0.CO;2-4

Sohrabi, C., Alsafi, Z., O'Neill, N., Khan, M., Kerwan, A., Al-Jabir, A., Iosifidis, C., \& Agha, R. (2020). World Health Organization declares global emergency: A review of the 2019 novel coronavirus (COVID-19). International Journal of Surgery, 76, 71-76. https://doi.org/10.1016/j.ijsu.2020.02.034

Taber, K. S. (2018). The Use of Cronbach's Alpha When Developing and Reporting Research Instruments in Science Education. Research in Science Education, 48(6), 1273-1296. https://doi.org/10.1007/s11165-016-9602-2

Tajeddini, K., \& Ratten, V. (2020). The moderating effect of brand orientation on inter-firm market orientation and performance. Journal of Strategic Marketing, 28(3), 194-224.

https://doi.org/10.1080/0965254X.2017.1293138

Teece, D. J. (2012). Dynamic Capabilities: Routines versus Entrepreneurial Action. Journal of Management Studies, 49(8), 1395-1401. https://doi.org/10.1111/j.1467-6486.2012.01080.x

Teece, D. J. (2014). The Foundations of Enterprise Performance: Dynamic and Ordinary Capabilities in an (Economic) Theory of Firms. Academy of Management Perspectives, 28(4), 328-352. https://doi.org/10.5465/amp.2013.0116

Teece, D. J. (2018). Business models and dynamic capabilities. Long Range Planning, 51(1), 40-49. https://doi.org/10.1016/j.lrp.2017.06.007

Teece, D. J. (2019). A capability theory of the firm: an economics and (Strategic) management perspective. New Zealand Economic Papers, 53(1), 1-43. https://doi.org/10.1080/00779954.2017.1371208

Teece, D. J., Pisano, G., \& Shuen, A. (1997). Dynamic capabilities and strategic management. Strategic Management Journal, 18(7), 509-533. https://doi.org/10.1002/(SICI)1097-0266(199708)18:7<509::AIDSMJ882>3.0.CO;2-Z

Uhlaner, L. M., Stel, A., Duplat, V., \& Zhou, H. (2013). Disentangling the effects of organizational capabilities, innovation and firm size on SME sales growth. Small Business Economics, 41(3), 581-607. https://doi.org/10.1007/s11187-012-9455-7

Ursachi, G., Horodnic, I. A., \& Zait, A. (2015). How Reliable are Measurement Scales? External Factors with Indirect Influence on Reliability Estimators. Procedia Economics and Finance, 20, 679-686. https://doi.org/10.1016/S2212-5671(15)00123-9

Wade, M., \& Hulland, J. (2004). Review: The Resource-Based View and Information Systems Research: Review, Extension, and Suggestions for Future Research. MIS Quarterly, 28(1), 107. https://doi.org/10.2307/25148626

Wang, C. L., \& Ahmed, P. K. (2007). Dynamic capabilities: A review and research agenda. International Journal of Management Reviews, 9(1), 31-51. https://doi.org/10.1111/j.1468-2370.2007.00201.X

Wang, Y., \& Shi, X. (2011). Thrive, not just survive: enhance dynamic capabilities of SMEs through IS competence. Journal of Systems and Information Technology, 13(2), 200-222. https://doi.org/10.1108/13287261111136016

Wilden, R., \& Gudergan, S. P. (2015). The impact of dynamic capabilities on operational marketing and technological capabilities: investigating the role of environmental turbulence. Journal of the Academy of Marketing Science, 43(2), 181-199. https://doi.org/10.1007/s11747-014-0380-y

Wood, V. R., Bhuian, S., \& Kiecker, P. (2000). Market Orientation and Organizational Performance in Not-forProfit Hospitals. Journal of Business Research, 48(3), 213-226. https://doi.org/10.1016/S0148-2963(98)00086-1

Yang, D., Wei, Z., Shi, H., \& Zhao, J. (2020). Market orientation, strategic flexibility and business model innovation. Journal of Business \& Industrial Marketing, 35(4), 771-784. https://doi.org/10.1108/JBIM-12-2018-0372

Yu, Q., Yen, D. A., Barnes, B. R., \& Huang, Y. (2019). Enhancing firm performance through internal market orientation and employee organizational commitment. The International Journal of Human Resource Management, 30(6), 964-987. https://doi.org/10.1080/09585192.2017.1380059 